\title{
Peran Orang Tua Untuk Meningkatkan Kualitas Ibadah Keluarga Berdasarkan Ulangan 6:7
}

\author{
Sarwedy Nainggolan*1, Stimson Hutagalung ${ }^{2}$, Rolyana Ferinia ${ }^{3}$ \\ ${ }^{1}$ Magister Filsafat Universitas Advent Indonesia \\ ${ }^{2,3}$ Dosen Universitas Advent Indonesia \\ *nainggolan.sarwedy@gmail.com
}

\begin{abstract}
This study was developed with the aim of analyzing the role of parents in improving the quality of family worship based on the book of Deuteronomy 6:7. This study use a qualitative method by descriptive approach using literature and journal studies. The results of the study indicate that the inculcation of spiritual and religious values must be carried out by parents. The word 'teach' in this verse uses the Hebrew word shannan and the word shânan here uses the root form of the Piel PERFECT type which means to whet or to sharpen, in Ugarit this is interpreted as the act of repeating, expressing an active process so that shânan is interpreted by teaching diligently. A similar emphasis to the word 'to speak' which comes from the Hebrew word dâbar also uses the Piel form to mean to talk continuously. Shânan and dâbar can be done in well-organized family worship in the morning ang evening as exemplified by parents. Parents can 'teach diligently' by linking children's activities with knowledge of God, at any time and at every opportunity. Parents are important educators for their children to forge, educate, train, guide and discipline their children by promoting peace and harmony.
\end{abstract}

Keywords : Family, Parents, Worship.

Abstrak: Penelitian ini dikembangkan dengan tujuan untuk menganilisa peran orang tua dalam meningkatkan kualitas ibadah keluarga berdasarkan kitab Ulangan 6:7. Penelitian ini menggunakan metode kualitatif melalui pendekatan deskriptif dengan menggunakan studi pustaka dan jurnal. Hasil penelitian yang diperoleh menyatakan bahwa penanaman nilai-nilai rohani dan keagamaan harus dilakukan oleh orang tua. Kata 'mengajarkan' dalam ayat ini menggunakan kata Ibrani shânan dan kata shânan di sini menggunakan bentuk kata dasar jenis Piel PERFECT yang dimaknai mempertajam atau mengasah, di Ugarit ini dimaknai tindakan mengulang, menyatakan proses aktif sehingga shânan diartikan dengan mengajarkan berulang-ulang. Penekanan serupa dengan kata 'membicarakan' yang berasal dari kata Ibrani dâbar juga menggunakan bentuk Piel sehingga diartikan membicarakan terus menerus. Shânan dan dâbar dapat dilakukan dalam ibadah keluarga yang teratur pada pagi dan petang yang dicontohkan oleh orang tua. Orang tua dapat 'mengajarkan berulang-ulang' dengan menghubungkan aktifitas anak dengan pengenalan akan Tuhan, di setiap waktu dan di setiap kesempatan. Orang tua adalah sebagai pendidik eminen kepada anak-anaknya untuk menempa, mengedukasi, melatih, menuntun dan mendisiplin anak-anaknya dengan mengasung kententraman dan keharmonisan.

Kata Kunci : Ibadah, Keluarga, Orang tua

\begin{tabular}{llll}
\hline Article History : & Received: 08-06-2021 & Revised: 15-12-2021 & Accepted: 22-12-2021
\end{tabular}




\section{Pendahuluan}

Pada zaman sekarang ini banyak keluarga Kristen yang kurang memberi perhatian terhadap pentingnya pembinaan rohani bagi anak-anak mereka ${ }^{1}$ di dalam keluarga. Para orang tua lebih sibuk memikirkan pekerjaan dan karir daripada memberikan perhatian kepada anak-anak mereka. ${ }^{2}$ Bahkan Utami mengatakan sebagaimana dikutip Nuraini, beberapa orang tua mempercayakan tanggung jawab sepenuhnya kepada pengasuh anak atau babysitter untuk mengasuh anak mereka ${ }^{3}$ dan pembinaan rohani dipercayakan kepada gereja dan sekolah. Hal ini menyebabkan kebutuhan mental, kasih sayang dan rohani anak tidak terpenuhi dengan baik. Akibatnya anak-anak tidak tertarik terhadap hal-hal rohani dan tidak mau terlibat dalam pelayanan gereja bahkan tingkah laku anak pun tidak terkontrol atau sering dikenal dengan kenakalan anak. Padahal, pendidikan di rumah tanggalah hal yang sangat berperan penting dalam pembinaan rohani dan karakter anak. $^{4}$

Beberapa orang tua yang beranggapan bahwa pembinaan rohani dan pendidikan moral cukup diberikan oleh para guru di sekolah dan dari gereja. Mereka beranggapan bahwa pembinaan rohani adalah tanggung jawab para guru di sekolah. ${ }^{5}$ Mereka tidak menyadari bahwa kerohanian dan pola hidup anak mereka di kemudian hari sangat tergantung pada pendidikan dan pengarahan ataupun pengaruh dari keluarga sendiri. Maka tidak jarang ditemukan anak yang tidak tertarik pada kegiatan agama dan hal-hal yang bersifat rohani sehingga muncul perilaku tidak baik, nakal, tidak sopan. Bahkan seseorang yang tidak memperoleh pengetahuan agama dengan benar memiliki kecenderungan untuk tidak patuh pada ajaran agama. Dan bila seseorang tidak patuh pada ajaran agama akan sangat mudah masuk pada tindakan tidak terpuji bahkan melakukan perbuatan yang jahat dan terkutuk. ${ }^{6}$ Ini disebabkan karena seringkali para orang tua yang lalai dalam tugas dan tanggung jawabnya untuk membina kerohanian anak-anaknya.

${ }^{1}$ EGW Writings Application Indoneisan Version 6.0.5, Membina Anak yang Bertanggung Jawab (Ellen G. White Estate, Inc., 2020), 69.

2 Exnasius Indriyanto, Pengaruh Pola Asuh Orang Tua Terhadap Iman Anak (Yogyakarta: Sanata Dharma, 2008), 3.

${ }^{3}$ Nuraini Wahyuningtyas, "Kasjian Tentang Pengasuhan Babysitter Terhadap Kemampuan Berbicara Anak Usia 2-3 Tahun" (Skripsi Fakultas Ilmu Pendidikan, Universitas Negri Semarang, 2016), 24.

4 Membina Anak yang Bertanggung Jawab, 13.

5 EGW Writings for Android, Child Guidance (Ellen G. White Estate, Inc., 2013), 334.

${ }^{6}$ Kartini Kartono, Patolongi Sosial 2 Kenakalan Remaja (Jakarta: Rajawali, 1986), 59. 
Syamsu Yusuf mengatakan nilai-nilai keagamaan dalam keluarga kurang didapatkan seorang remaja, maka kondisi tersebut akan mengakibatkan bertumbuhnya perbuatan dan perilaku remaja yang kurang baik ataupun perbuatan asusila seperti pergaulan bebas bahkan seks bebas, minum-minuman keras, menggunakan obat terlarang juga menjadi sumber persoalan perongrong ketertiban dan pemicu keributan dalam masyarakat. ${ }^{7}$ Bahkan bila kehidupan dalam keluarga yang tidak baik dan nyaman bagi anak, apalagi sampai seorang anak tidak memperoleh kasih sayang dari orang tua dan berteman dengan kelompok sebaya sebagaimana mestinya oleh karena kurang menghargai hal-hal yang bernilai rohani. Yusuf juga menambahkan bahwa peyebab utama kenakalan remaja ialah kurangnya pendidikan rohani dalam kehidupan keluarga. Sebab pendidikan keagamaan memiliki dampak yang sangat besar terhadap moral seseorang dan nilai-nilai moral yang ditanamkan melalui agama bersifat tetap dan konsisten karena tidak dipengaruhi oleh masa dan lingkungan. Oleh sebab itu sangatlah penting bagi orang tua perlu melakukan pembinaan agama sejak dini bagi anak-anak mereka, hal ini dapat dilakukan dengan memberi bimbingan rohani dan pengajaran moral sehingga anak-anak dapat membedakan dengan baik tindakan mana yang akan mereka lakukan antara yang baik atau buruk dalam kehidupan sehari-hari. ${ }^{8}$

Proses pertumbuhan kerohanian anak bukanlah tanggung jawab gereja dan sekolah semata. Orang tua adalah orang yang sangat berpengaruh dan yang pertama bertanggung jawab terhadap pertumbuhan anak sejak anak dilahirkan, baik secara fisik, mental dan rohani. Setiap orang tua harus menyadari bahwa peranan mereka akan berkurang dari tahun ke tahun sampai kelak anak tumbuh dewasa dan meninggalkan rumah mereka sebagai anak yang mandiri. Orang tua harus sadar bahwa mereka harus memberikan waktu bersama anak-anak mereka dengan didikan yang berlandaskan Firman Allah dan mempengaruhi anak melakukan tindakan yang sesuai dengan kehendak Allah.

Sehubungan dengan penjelasan di atas kita harus menyadari bahwa semua kita membutuhkan tuntunan yang dapat menuntun kita menjalani kehidupan dengan segala tantangan dan kesulitannya seperti seorang nakhoda kapal ketika mengarungi lautan. Dalam hal ini, Alkitab adalah penuntun yang tepat dan berguna sebab Kitab Suci ini dituliskan oleh orang-orang suci atas ilham dari Allah. Alkitab memberikan penjelasan yang baik dan tepat tentang tanggung jawab orang tua dan orang muda. Betapa

\footnotetext{
${ }^{7}$ Syamsu Yusuf, Psikologi Perkembangan Anak dan Remaja (Bandung: Remaja Rosda Karya, 2004),
} 70.

8 Ibid., 71. 
beruntungnya bilamana menjadikannya sebagai pedoman dan penasihat dalam menjalani hidup setiap hari. ${ }^{9}$

Berdasarkan kitab Ulangan 6:6-7 dapat diartikan bahwa keluarga adalah tempat menetapkan kepribadian anak menuju pada kedewasaan dan tempat pemberitaan injil. Maka mengajarkan berulang-ulang menjadi sangat penting. Darmawan berpendapat informasi yang diterima secara berulang akan menimbulkan perekaman berulang-ulang juga sehingga dapat diingat dengan baik, bahkan memungkinkan pemahaman yang lebih baik. ${ }^{10}$ Salah satu wujud ungkapan kasih kepada Allah dari para orang tua ialah dengan memperhatikan kesejahteraan rohani anak-anak mereka dan berupaya menuntun mereka untuk tetap setia kepada Allah dalam hubungan pribadi, yang mana orang tua bertanggung jawab untuk melakukan bimbingan dan pembinaan dalam hal ini.

Bertolak dari uraian diatas, penelitian ini dibuat dengan tujuan untuk menyelidiki peran orang tua untuk meningkatkan kualitas ibadah keluarga berdasarkan kitab Ulangan $6: 7$.

\section{Metode Penelitian}

Metodologi yang digunakan dalam penelitian ini adalah metodologi penelitian kualitatif 11 dengan pendekatan deskriptif yaitu metode yang dalam menemukan hasilnya tidak diperoleh dengan menggunakan statistik atau jenis perhitungan lainnya. ${ }^{12}$ Metode penelitian kualitatif merupakan penelitian yang berfokus pada pengamatan dan kajian yang mendalam atas satu fenomena yang komprehensif. 13

Menurut Gill, sebagaimana dikutip oleh Yoni Ardianto dalam laman Kementerian Keuangan Republik Indonesia, teknik pengumpulan data dalam penelitian kualitatif ada beberapa macam yaitu, dengan melakukan observasi, analisis visual, studi pustaka. ${ }^{14} \mathrm{Di}$ sini penulis melakukan teknik pengumpulan data dengan cara observasi lapangan secara langsung, studi pustaka dari berbagai buku dan jurnal yang berhubungan dengan topik

\footnotetext{
${ }^{9}$ EGW Writings for Android, Testimonies for the Church (Ellen G. White Estate, 2013), 5:264.

10 I Putu Ayub Darmawan, "Pembelajaran Memorisasi dalam Ulangan 6:6-9," EPIGRAPHE: Jurnal Teologi dan Pelayanan Kristiani 3, no.1 (Mei 2019) : 24.

${ }^{11}$ Eko Sudarmanto et al., Desain Penelitian Bisnis: Pendekatan Kuantitatif (Medan: Medan: Yayasan Kita Menulis, 2021).

12 Dr. Farida Nugrahani, M.Hum., Metode Penelitian Kualitatif Dalam Penelitian Pendidikan Bahasa (Surakarta: 2014), 9.

13 Kementerian Keuangan Republik Indonesia, "Memahami Metode Penelitian Kualitatif" https://www.djkn.kemenkeu.go.id (diakses 14 July 2021, 09.28 WITA)

14 Brigitte Smit, “Observations in Qualitative Inquiry: When What You See Is Not What You See," (Sagepub: International Journal of Qualitative MethodsVolume 17: 1-3): 1.
} 
yang dikaji. Penyelidikan alkitabiah dilakukan dengan metode hermeneutika untuk memperoleh makna yang mendalam dan tepat sesuai pada konteks penulisan teks ayat Alkitab itu sendiri.

\section{Hasil dan Pembahasan}

\section{Orang tua dan Keluarga}

Orang tua ialah ayah ibu kandung; atau orang yang dituakan karena kepandaian, cerdik atau keahliannya; ${ }^{15}$ dan lebih jauh lagi Soelaeman berpendapat “... sebutan orang tua sebaiknya tidak selalu dimaknai sebagai orang yang lanjut usia namun sebagai orang yang dituakan karena diberi tanggung jawab untuk mengasuh dan membimbing anaknya hingga dewasa."16 Hitami berpendapat bahwa orang tua ialah pendidik mula-mula serta yang utama untuk anak-anaknya, sebab dari orang tualah anak-anak mulai mendapatkan pembelajaran. Kesuksesan anaknya ialah sukses orang tua pula. Adalah kewajiban orang tua untuk bertindak dan bertanggung jawab atas pembelajaran anak, sebab anak ialah pemberian Allah yang wajib dilindungi serta dipertanggungjawabkan dengan baik, dengan teknik mencermati keseimbangan dalam hal material serta spiritual, komponen badani serta rohani anak-anaknya. ${ }^{17}$

Kamus Besar Bahasa Indonesia ${ }^{18}$ dan Kamus Besar Bahasa Indonesia Kontemporer ${ }^{19}$ kedua-duanya memberikan ide yang sama tentang pengertian keluarga yaitu menekankan bahwa yang disebut keluarga adalah yang terdiri dari ibu, ayah, dan anak-anak, atau seisi rumah yang menjadi tanggungan, atau yang ada hubungan darah, juga menekankan suatu kekerabatan. Jerry, Veda dan Albert menegaskan dengan mengatakan bahwa lembaga pendidikan yang pertama dan utama dalam menciptakan manusia sejati adalah keluarga. Dalam membentuk manusia sejati, peran orang tua sangatlah vital dimana orang tua akan memberi pengaruh terhadap kualitas anak yang dibina dalam rumah tangga mereka. Dari dalam rumah tanggalah seorang anak mendapat pengajaran tentang hidup beriman, disana juga memperoleh nilai kemanusiaan dan hidup. Melalui pendidikan dalam keluarga, dengan komunikasi yang hangat dan

15 Departemen Pendidikan Nasional, Kamus Besar Bahasa Indonesia, $2^{\text {nd }}$ ed. (Jakarta: Balai Pustaka, 2005), 802.

16 M.I Soelaeman, Pendidikan Dalam Keluarga (Bandung: Alfabeta, 1994), 179.

${ }^{17}$ H. Munzir Hitami, Mengonsep Kembali Pendidikan Islam (Yogyakarta: LkiS, 2004), 26.

18 Departemen Pendidikan dan Kebudayaan, Kamus Besar Bahasa Indonesia, $2^{\text {nd }}$ ed. (Jakarta: Balai Pustaka, 1987), s.v “Keluarga."

19 Peter Salim, Kamus Bahasa Indonesia Kontemporer, $3^{\text {rd }}$ ed. (Jakarta: Balai Pustaka, 1991), s.v. "Keluarga." 
hubungan yang baik di dalam keluarga yang dipelihara dengan menghormati setiap anggota keluarga juga anak-anak memiliki kejujuran, toleransi dan menjadi manusia sejati. 20

\section{Kata Mengajarkan dan Membicarakan}

Kitab Ulangan (debarim : perkataan-perkataan) merupakan nasehat perpisahan Musa kepada generasi Israel yang baru dengan mengulang dan memperbaharui kembali perjanjian Allah dengan Israel. ${ }^{21}$ Pada kitab Ulangan 6 Musa mengingatkan orang Israel agar tidak melupakan kebesaran Tuhan dalam perjalanan hidup mereka, mengajarkan segala perintah Allah dan mengasihi Dia. Antone berpendapat bahwa pendidikan dalam ulangan 6 ini menyiratkan pola hidup dalam keluarga Israel dengan menekankan pemeliharaan iman. ${ }^{22}$ Dalam kitab Ulangan 6:7 terdapat dua kata kunci yang harus diperhatikan. Kata itu adalah kata 'ajar' atau 'mengajarkan' dan kata 'membicarakan.' Matthew Henry mengomentari ayat ini dengan mengatakan bahwa hal ini menjadi sarana untuk menjaga dan memelihara agama tetap ada di dalam hati dan di dalam rumah kita. ${ }^{23}$

Musa mengawali pasal 6 dengan kalimat 'inilah perintah' yang diulangi pada ayat 6 'kuperintahkan.' Perintah yang dimaksudkan Musa disini yaitu perintah Tuhan, peringatan dan ketetapan Tuhan (ayat 1, 17) serta mengasihi Tuhan Allah dengan segenap hati, jiwa dan kekuatan (ayat 5). Dalam kitab Perjanjian Baru Yesus menyebut ini sebagai perintah Allah yang utama dan yang pertama (Mat.22:37,38; Mark 12:29,30). Selanjutnya hal ini harus diajarkan 'berulang-ulang kepada anak-anakmu' sebagai bukti kecintaan pada Allah. Orang tua bertanggung jawab mengajarkan firman Tuhan dalam keluarga; penghayatan dan pemahaman firman Tuhan dilakukan dalam bimbingan orang tua. Ini mendukung pendapat Sjamsuri bahwa menciptakan persekutuan ibadah keluarga adalah tanggung jawab orang tua. ${ }^{24}$ Mengajarkan dan membicarakan berulang-ulang menjadi penting dilakukan terus menerus agar dapat dipahami dengan baik, 'supaya baik keadaanmu' (ayat 3) dan 'supaya jangan bangkit murka Tuhan' (ayat 15). Cara terbaik yang dapat dilakukan oleh orang tua untuk mengekspresikan kasih dan kesetiaan kepada

20 Jerry Rudolf Sirait, Ied Veda Sitepu dan Albert M Hutapea, Sekarang, Bangkit dan Berdirilah, Jangan Goyah (Jakarta: PrimaLogi Press, 2004), 78.

${ }^{21}$ Clifford R. Goldsteini, Kebenaran Zaman Ini dalam Kitab Ulangan (Bandung: Yayasan Penerbit Advent Indonesia, 2021), 12-13.

${ }^{22}$ Hope S. Antone, Pendidikan Kristiani Kontekstual (Jakarta: BPK Gunung Mulia, 2010), 18.

23 Online Bible Study Suite, "Matthew Henry's Commentary, Deuteronomy 6" https://biblehub.com Accessed July 21, 2021. 2016), 34.

${ }^{24}$ Leonardo A. Sjamsuri, Keluarga Bahagia Ditengah Perubahan Zaman (Jakarta: Nafiri Gabriel, 
Tuhan adalah dengan mengutamakan pertumbuhan rohani anak-anak mereka dan membimbing mereka agar tetap setia dan selalu memiliki hubungan yang baik dengan Tuhan.

\section{Mengajarkan}

Dalam Alkitab Terjemahan Baru ditulis "haruslah engkau mengajarkannya berulang-ulang." Kata Ibrani yang digunakan dalam kata ini adalah שנן (shânan atau shaw-nan) ${ }^{25}$ yang dapat diartikan: mengesankan, mempengaruhi, mencamkan, menanamkan kesan. Kata shânan di ayat ini diartikan dengan kata 'ajar' dan kata 'ajar' dalam ayat ini yaitu kata shânan menggunakan bentuk kata dasar jenis Piel26 PERFECT yang artinya mempertajam. ${ }^{27}$ Kata dalam bentuk Piel menunjukkan penekanan yang kuat/intesif, sebuah ungkapan penguatan dari akar kata ( $Q a l)$ tertentu menjadi intensif seperti tertawa ( $Q a l$ ) menjadi tertawa berulang-ulang (Piel). ${ }^{28}$ Di dalam bahasa Inggris diterjemahkan dengan 'whet' (mengasah) dan 'sharpen' (mempertajam). Dalam format Piel, menggambarkan keadaan yang aktif dan menunjukkan tindakan yang berkelanjutan dan menjadi suatu status keberadaan. Merupakan kata dasar Qal yang diperkembangkan atau diekspansi menjadi suatu keadaan yang baru. ${ }^{29}$

Mengajarkan disini berarti memberikan, menerangi dan membuka wawasan seseorang, dalam hal ini harus dilakukan secara berulang-ulang. Ayat ini, dalam bahasa aslinya, bahasa Ibrani tidak menggunakan kata 'berulang-ulang' yang dalam kitab bahasa Inggris 'diligently', tetapi karena kata shânan yang digunakan ini adalah dalam bentuk Piel maka penekanannya lebih tajam. Di Ugarit sebutan ini dimaknai "mengulang." Sepertinya itulah pesan utama ayat ini. Dan ayat ini sering kali digunakan oleh para rabi dalam meneguhkan bahwa shânan harus "diulang" pagi dan sore hari. Berbicara tentang kerinduan Tuhan bagi kita dalam semua sisi kehidupan adalah kewajiban kita setiap hari. Orang tua berkewajiban untuk mewariskan pola hidup beriman ini. ${ }^{30}$ Adam Clark mengatakan bahwa mengajar di sini adalah merupakan pekerjaan yang sangat penting,

${ }^{25}$ Rick Meyers, e-Sword Electronic edge (www.e-Sword.net, 2020).

${ }^{26}$ John Joseph Owens, Analytical Key to the Old Testament, vol. I (Grand Rapids, Michigan: Baker Book House Company, 1990), 783.

${ }^{27}$ Bob Utley, Kumpulan Komentari Panduan Belajar, Vol. 3 (Texas: Bible Lesson International, 2005), 95.

${ }^{28}$ Geoffrey Stewart Morrison, Teaching the Classical Hebrew Stem System (British Columbia: Vancouver School of Theology, 1995), 10.

${ }^{29}$ Bob Utley, Kumpulan Komentari Panduan Belajar, Vol. 3 (Texas: Bible Lesson International, 2005), v.

${ }^{30}$ Ibid., 95. 
yang terbaik dan merupakan cara paling efektif untuk membangun tabiat anak. Meski hal ini merupakan tugas yang sulit dan membutuhkan kesabaran, kebijaksanaan, keadilan dan kesalehan dari para orang tua untuk melakukan yang terbaik. ${ }^{31}$ Namun orang tua dapat menembus masuk ke dalam hati anak-anak mereka dengan rajin, sungguh-sungguh, sering dan hati-hati, sebagaimana dalam metafora ini. ${ }^{32}$ Dalam SDA Bible Commentary dituliskan bahwa kata 'teach' atau mengajar disini memiliki arti 'mengasah atau mempertajam pikiran.' Panggilan ini dengan jelas untuk mengajar atau perintah untuk mengajar. Kepada orang tua diberi tanggung jawab yang penting yaitu mengajarkan anak-anak dalam segala kewajiban dan keagungan hari demi hari. ${ }^{33}$

\section{Membicarakan}

Kata penting berikutnya dalam ayat ini adalah kata 'bicara' atau 'membicarakan.' Dalam ayat ini selanjutnya dituliskan “... haruslah engkau membicarakannya ...” Kata 'membicarakan' yang digunakan dalam ayat ini berasal dari kata דבר (dâbar)34, yang dalam teks bahasa Ibrani kata dâbar berarti percakapan, pembicaraan, perbincangan, ceramah, omongan, berbicara. Sebagaimana kata shânan yang terdapat dalam ayat ini, kata 'dâbar' juga menggunakan bentuk Piel. Sehingga memiliki penekanannya yang sama dengan tujuan yang hampir sama, yaitu membicarakan kebenaran secara terus menerus.

\section{Kapan Harus Diajarkan Dan Dibicarakan?}

Paragraf Ulangan 6:7 ini diawali dengan seruan di ayat 4 shema (שֵַָׁ yang berarti 'dengarlah.' Seruan ini disampaikan setiap hari secara tetap agar mengasihi Tuhan, satusatunya Allah yang patut disembah secara sadar dengan hati yang sungguh melakukan peribadatan. Melalui Musa, Allah ingin agar perintahNya ini melekat di hati umatNya maka perlu diajarkan dan dibicarakan berulang-ulang. Stanley W. Heath berpendapat bahwa shema bukan perintah yang dikhususkan hanya pada bangsa Israel tetapi juga pada orang tua masa kini. ${ }^{35}$ Ulangan 6:7 menuliskan bahwa pengajaran tentang

\footnotetext{
${ }^{31}$ Adam Clark, A Commentary and Critical Notes (New York: The Methodist Book Concern, 1984), $3: 755$.

32 Online Bible Study Suite, "Benson Commentary, Deuteronomy 6" https://biblehub.com Accessed July 21, 2021.

33 “Teach" (Deutronomy 6:7), The Seventh-Day Adventist Bible Commentary, ed. Francis D. Nichol (Washington, D C.: Review and Herald, 1978), 1:974.

${ }^{34}$ Rick Meyers, e-Sword Electronic edge (www.e-Sword.net, 2020).

35 Stanley Warren Heath, Keluarga Kristen: Antisipasi Pengaruh Pendidikan Global dalam Keluarga(Bandung: Biji Sesawi, 2016), 32.
} 
pengenalan akan Allah itu harus dilakukan ketika duduk, dalam perjalanan, berbaring atau bangun. Terminologi ini bersifat representasi, yang mana merupakan cakupan semua aktifitas sehari-hari manusia sejak pagi hingga malam hari. ${ }^{36}$ Deane dan Taylor memberikan pendapat tentang tugas orang tua terhadap anak-anaknya berdasarkan 'pada waktu duduk, dalam perjalanan, dan berbaring atau bangun yaitu: 1) Orang tua bertugas untuk menjawab secara penuh pertanyaan anak-anak. 2) Orang tua bertanggung jawab untuk menyatakan maksud dan keberadaan Allah. 3) Orang tua mempunyai tugas untuk mempromosikan kebenaran kepada anak-anaknya. ${ }^{37}$

\section{Apabila engkau duduk}

Konsep pembentukan tabiat anak dalam pernyataan "apabila engkau duduk" dalam ayat ini menyatakan keharusan adanya pendalaman agama di rumah sama seperti di gereja ataupun di kaabah. Membuat keluarga menjadi mezbah peribadatan yang mulia di hadapan Tuhan. Dengan kata lain agama harus menjadi prioritas di dalam rumah tangga karena kesaksian tentang Allah harus diajarkan kepada anak-anak dalam kebaktian di rumah dan disampaikan dengan cara yang bijaksana supaya mereka mengerti dan memahami. ${ }^{38}$ Contoh penerapannya di dalam keluarga adalah dengan mengadakan ibadah renungan pagi dan renungan malam. Secara tidak langsung, ini menyampaikan pesan betapa pentingnya duduk bersama anak-anak dan menyelidiki firman Tuhan.

\section{Apabila dalam Perjalanan}

Interpretasi terhadap kata 'dalam perjalanan' disini menekankan keharusan akan adanya pendalaman keagamaan di luar rumah sebagaimana yang dilakukan di dalam rumah, menunjukan atau menyaksikan keagungan Allah ke manapun kita pergi dengan selalu membicarakan tentang Tuhan kepada anak-anak. ${ }^{39}$ Contohnya dengan mengadakan rekreasi keluarga, atau mengikuti perkemahan rumah tangga dari gereja. Alexander menyatakan harus ada pendalaman keagamaan di luar rumah, sama seperti yang dilakukan di dalam rumah dan tidak merasa malu bersaksi tentang keagungan Allah tersebut melalui agama kita ke manapun kita pergi. ${ }^{40}$ Senada dengan itu Joseph

36 I. J. Cairns, Tafsiran Alkitab Kitab Ulangan,_Jilid I (Jakarta: Gunung Mulia, 1997), 135.

37 W.J. Deane dan S.T. Taylor Taswell, The Pulpit Commentary, ed. H.D.M. Spence dan Joseph Exell (Grand Rapids, MI: Eerdmans, 1950), 1:130.

${ }^{38}$ Adam Clark, 3:755.

${ }^{39}$ Ibid., 755.

${ }^{40}$ W.L. Alexander, The Pulpit Commentary, vol. III (Grand Rapids MI: Wm. B. Eerdmans Publishing Company, 1980), 3:119. 
mengatakan agar setiap saat orang tua menggunakan waktu untuk mendidik anak, hal ini juga berarti memberikan pengajaran di mana saja dan kapan saja. ${ }^{41}$

\section{Berbaring dan bangun.}

Penerapan "apabila engkau berbaring dan apabila engkau bangun" dalam pembentukan tabiat dan kerohanian anak berarti semua sisi kehidupan harus diawali dan diakhiri bersama dengan Tuhan setiap hari, sebagaimana halnya tidur dan bangun merupakan bagian dari aktifitas kehidupan sehari-hari dan nilai keagamaan haruslah menjadi urusan yang sangat penting dalam kehidupan kita. ${ }^{42}$ Contohnya dengan menceritakan cerita Alkitab sebelum anak tidur, berdoa sebelum tidur dan saat bangun. Ini mengartikan agar keseharian kita selalu mengutamakan Tuhan dan usaha seperti ini harus menjadi rutinitas keluarga secara terus-menerus. Gill's memberikan penjelasan pengajaran ini dapat ditingkatkan dengan membiasakan anak untuk berkomunikasi dengan Tuhan melalui doa ketika menjelang tidur maupun ketika bangun. ${ }^{43}$

Tafsiran yang dituliskan oleh Robert Jamieson terhadap ayat ini berdasarkan bahasa aslinya adalah 'thou shalt sharpen them'. Disini Musa mungkin hanya menggunakan ungkapan figuratif sebagai instruksi untuk tekun, sungguh-sungguh dan sering. Tapi metode pengajaran pada bangsa Israel pada umumnya adalah secara lisan. Ini merupakan perintah untuk mengajar anak-anak mereka dari sejak bayi yaitu dengan menyampaikan kebenaran Allah melalui Kesepuluh Firman dan hukum yang lain dengan cara berbicara pada setiap kesempatan.

\section{Ibadah Keluarga}

Ibadah keluarga merupakan bentuk perbaktian yang biasa dalam Perjanjian Lama. Misalnya Abraham, beberapa kali mendirikan mezbah bersama keluarganya (Kej.12:8, 13:18) namun tidak satupun meyebutkan ibadah itu dipimpin oleh seorang imam. ${ }^{44}$ Maka patut diduga kepala keluarga berperan memimpin ibadah-ibadah itu sebagai imam. Namun dalam Ulangan 4 umat Israel didapati turut bergabung dalam praktik kekafiran dan penyembahan Baal-Peor. ${ }^{45}$ Tentu panggilan Musa menjadi sangat penting untuk kembali mengingat perjanjian dengan Allah yang benar.

\footnotetext{
41 Joseph S. Exell, The Pulpit Commentary (New York: Funk and Wagnalls, 1950), 3:119.

42 Adam Clark, 3:755.

43 Online Bible Study Suite, “Gill's Exposition, Deuteronomy 6" https://biblehub.com Accessed July

${ }^{44}$ HH. Rowlley, Ibadat Israel Kuno (Jakarta: BPK Gunung Mulia, 2012), 16.

45 Clifford, 61.
} 20,2021 . 
Seperti yang sudah dijelaskan sebelumnya, Ulangan 6:6,7 dalam penjelasannya menekankan betapa pentingnya menanamkan nilai-nilai agama di dalam keluarga, yang mana ini dapat diterapkan seperti melakukan ibadah keluarga dengan tertib dan teratur. Sebagai orang kristen, para orang tua berkewajiban untuk mengajarkan anak-anak ilmu yang bersumber dari Alkitab, bukan tentang pengetahuan umum saja, tetapi pengenalan akan Allah. Kita harus mengakui bahwa memang ada banyak hal yang harus diajarkan oleh orang tua pada anak, namun yang paling utama dari semuanya adalah Firman Allah, ini bermanfaat untuk membentuk tabiat. Maka perlu mengatur waktu yang tepat dan tetap sedemikian rupa untuk dapat mempelajari Alkitab dengan semua anggota keluarga dan menyelidiki Kitab Suci dengan tekun dan efektif. Keluarga harus menjadikan Tuhan sebagai pusat dari segalanya sebab Ia adalah sumber dari segala sesuatu maka segala sesuatu yang dipelajari, dikerjakan dan dilakukan akan berhasil. ${ }^{46}$

Setiap rumah tangga harus membuat mezbah doa dalam keluarga dan memahami bahwa awal dari segala kebijaksanaan ialah mengutamakan Tuhan. Oleh sebab itu, di dalam setiap rumah tangga harus menentukan waktu yang tetap bagi semua anggota keluarga untuk melakukan ibadah keluarga setiap pagi dan petang, maka semua anggota keluarga mengetahui kapan dan dimana ibadah keluarga dilakukan. Kebiasaan yang teratur seperti ini akan membuat semua dapat hadir tepat waktu dalam setiap ibadah keluarga, sementara jika tidak ditetapkan dengan baik maka tidak akan teratur. ${ }^{47}$ Lebih lanjut, setiap waktu melakukan ibadah keluarga di pagi dan petang harus menjadi saat yang menyenangkan dan ditunggu tiap hari. Di mana hal-hal yang tidak baik disingkirkan dan kesusahan serta kepenatan dilepaskan dari pikiran. Semua anggota keluarga, ayah, ibu dan anak duduk bersama-sama untuk menghadap Khalik dan meminta para malaikat yang kudus datang hadir dan memberkati keluarga. ${ }^{48}$

Dalam buku Nasihat Bagi Sidang, Ellen G. White lebih lanjut memberi nasihat kepada bapak-bapak dan ibu-ibu agar dengan konsisten setiap pagi dan petang mengadakan perbaktian keluarga, yang mana anak-anak dikumpulkan dan memanjatkan permohonan pada Allah agar selalu menolong. ${ }^{49}$ Pengenalan yang sungguh-sungguh dalam pengetahuan tentang Allah harus ditanamkan pada anak dilakukan dengan mengaitkan

${ }^{46}$ Clyde M. Narramore, Menolong Anak Anda Bertumbuh dalam Iman (Bandung: Yayasan Kalam Hidup, 1961), 23.

47 R.I Sarumpaet, Pedoman Rumah Tangga (Bandung: Indonesia Publishing House, 1991), 108.

${ }^{48}$ EGW Writings for Android, Education (Ellen G. White Estate, Inc., 2013), 186.

${ }^{49}$ Ellen G. White, Nasihat Bagi Sidang (Bandung: Indonesia Publishing House, 1998), 300. 
agama dalam semua aktifitas kehidupan keluarga secara berulang-ulang. ${ }^{50}$ Dalam kitab Amsal 22:6 disebutkan bahwa anak yang dididik sejak dini. Pulpit Commentary menuliskan mendidik disini ibarat seorang perawat menyuapi suatu makanan yang telah ia kunyah untuk mempersiapkan pada makanan selanjutnya demikianlah juga anak dididik sejak usia dini untuk jalan hidup yang akan ditempuhnya kelak. ${ }^{51}$ Hadinoto menegaskan, sebagaimana dikutip oleh Waharman bahwa pengajaran dari ayah dan ibu di dalam rumah harus diberikan sejak kecil agar dapat tertanam dalam diri anak untuk kehidupannya di masa yang akan datang. ${ }^{52}$

\section{Teladan Orang Tua}

Seorang bernama SJ. Sutjiono sebagaimana dikutip oleh Kavolder mengatakan bahwa ayah dan ibu harus mendidik anak-anaknya tentang pengenalan akan Tuhan dan harus menjadi teladan yang baik bagi mereka, di rumah maupun di luar rumah. ${ }^{53}$ Maka pengajaran tentang sabda Allah harus disampaikan bukan dengan teori semata tetapi harus dengan praktik nyata sesuai prinsip-prinsip kebenaran yang diajarkan. Sifat yang benar dalam kehidupan sehari-hari sangatlah memberikan kesan yang mana orang tua harus menunjukkan tabiat Allah dalam hidup mereka. ${ }^{54}$ Santi Hartian mengutip pernyataan James dan Merry yang berpendapat bahwa anak-anak sangat mudah meniru apa yang dilihatnya dari orang-orang dewasa yang dekat di sekeliling mereka; cara berpakaian, berbicara dan pilihan lagu dll. Bahkan anak-anak menganggap pantas dengan semua yang mereka tiru meskipun sebenarnya tidak cocok dengan usia mereka. 55 Kebiasaan yang dilakukan oleh orang tua menjadi contoh bagi anak-anak mereka. Hal-hal yang sehari-hari dilakukan orang tua sangat berdampak pada keimanan dan perilaku seorang anak sebab anak akan memperhatikan serta mengamatinya dan pada dasarnya

50 Online Bible Study Suite, "Jamieson-Fausset-Brown Bible Commentary, Deuteronomy 6" https://biblehub.com Accessed, July 20, 2021.

51 Online Bible Study Suite, "Pulpit Commentary, Deuteronomy 6" https://biblehub.com Accessed, July 20, 2021.

52 Waharman, "Peran Orang Tua Dalam Pertumbuhan Spiritualitas Anak: Sebuah Studi Eksegesis Efesus 6:1-4" Manna Rafflesia, 4/2 (April 2018), 120.

${ }^{53}$ Kavolder Togatorop, "Pengaruh Peningkatan Ibadah Dalam Keluarga Terhadap Karakter Remaja Kristen Di Yayasan Perguruan Anugerah Sinagoge SMPTK Medan” PROVIDENSI: Jurnal Pendidikan dan Teologi, Volume 3, Nomor 1 (Juni 2020): 57.

54 EGW Writings Application Indoneisan Version 6.0.5, Membina Pendidikan Sejati (Ellen G. White Estate, Inc., 2020), 36.

55 Santi Hartian, "Pengaruh Pembinaan Rohani Di Keluarga Terhadap Karakter Pemuda Berdasarkan Kolose 2: 6-10 Di GBAP Surakarta” Journal Fidei, Vol.2 No.1 (Juni 2019), 26 
anak sangat senang meniru dan mengikuti kemauan orang tua. ${ }^{56}$ Sebagaimana menurut Hutagalung bahwa orang tua harus menjadi contoh dalam menghormati kebaktian, dengan menjaga tingkah laku, perkataan dan sikap yang menunjukkan menghormati kebaktian. ${ }^{57}$

Sifat dan tindakan sehari-hari sangatlah berpengaruh dalam proses pembentukan tabiat dan kerohanian anak. Para ayah dan ibu harus mampu menjadi teladan dalam praktik kehidupan tiap-tiap hari bagi anak-anak mereka. Pikiran yang rohani sangatlah dipengaruhi oleh segala perilaku orang tua yang dilihat anak. Pikiran tentang keagamaan seorang anak sangat ditentukan oleh kehidupan sehari-hari di dalam keluarga. Seorang anak dapat memahami siapa Allah melalui pengalaman hidup bersama ayahnya. Melalui melihat orang tualah anak-anak memiliki pandangan tentang betapa berdosanya jika tidak menghormati orang tua, bagaimana orang tua mengampuni kesalahan mereka juga mengajarkan anak tentang pengampunan dan bagaimana menyadari kesalahan serta mengakuinya. Sifat dan kebiasaan yang baik pada anak hanya terwujud bilamana orang tua sebagai pendidik memberikan teladan. ${ }^{58}$ Teladan yang diberikan oleh orang tua memberikan pengaruh yang jauh lebih besar dibandingkan nasihat dan ajaran yang diberikan. ${ }^{59}$ Jadi peranan orang tua bukan hanya sekedar membicarakan firman Tuhan lewat perkataan saja, tetapi juga harus melalui tindakan yang nyata untuk dilihat oleh anak. Pendidikan dalam rumah tangga adalah fondasi yang menjadi dasar terbentuknya pikiran yang rohani, ${ }^{60}$ yang mana ini diperoleh melalui keteladanan orang tua dalam kehidupan. Teladan yang diberikan oleh orang tua sangat efektif karena anak-anak akan dapat memahami dengan mudah dan mengikutinya. ${ }^{61}$ Dengan demikian, setiap kesan yang tertanam dalam pikiran anak akan tetap diingat dan berkembang menjadi perilakunya. Itu sebabnya betapa pentingnya untuk memberikan perhatian pada

${ }^{56}$ Syaiful Bahri Djamarah, Pola Asuh Orang Tua dan Komunikasi dalam Keluarga, (Jakarta: Rineka Cipta, 2014), 53.

${ }^{57}$ Stimson Hutagalung \& Rolyana Ferinia, "Menjelajahi Spiritualitas Milenial: Apakah Membaca Alkitab, Berdoa, dan Menghormati Ibadah di Gereja Menurun?" Jurnal Teruna Bhakti” Volume 2, No 2, Pebruari 2020, 109.

58 Paristiyanti Nurwardani dkk, Buku Ajar Mata Kuliah Wajib Umum Pendidikan Agama Kristen, (Jakarta: Direktorat Jenderal Pembelajaran dan Kemahasiswaan Kementerian Riset Teknologi dan Pendidikan Tinggi, 2016), 86.

${ }^{59}$ Aby Gayel, Stimson Hutagalung dan Rolyana Ferinia, "Tantangan Mendidik Anak-Anak Pendeta di Gereja Masehi Advent Hari Ketujuh (GMAHK) DKI Jakarta Melalui Penerapan Disiplin dan Keteladanan" EDULEAD: Journal of Christian Education and Leadership Vol. 2, Edisi.1 (Juni 2021), 105

${ }^{60}$ Jalaluddin, Psikologi Agama, (Jakarta: Rajawali Pers, 2012), 194.

${ }^{61}$ Jarot Wijanarko, Mendidik Anak, (Banten: PT. Happy Holy Kids, 2012),11 
kerohanian anak sejak dini agar kehidupan masa depannya tetap menjadi orang kristen yang setia dan hidup sesuai dengan nilai-nilai rohani.

\section{Orang Tua Sebagai Pendidik}

Sebagai orang yang pertama mengajarkan sesuatu hal kepada anak maka orang tua berperan sebagai pendidik bagi anaknya. Pendidikan dari orang tua memberikan berbagai pengaruh nilai bagi anak. ${ }^{62}$ Sebagai pendidik pertama dalam rumah tangga, ayah dan ibu bertanggungjawab mengomunikasikan firman Tuhan dan sikap beribadah yang benar. Helmawati juga menyatakan bahwa pendidik memiliki kewajiban dalam menolong memajukan kemampuan anak dalam rohani, kecerdasan, fisik, moral maupun pemahaman lainnya. ${ }^{63}$ Pendidikan rohani atau pendidikan keagamaan dalam keluarga akan menanamkan nilai dan pandangan kehidupan yang mewarnai perkembangan jasmani dan akal. Maka keluarga sebagai tempat edukasi anak harus mengambil atensi terpenting para orang tua. ${ }^{64}$

\section{Memberikan Kenyamanan}

Lingkungan tempat tinggal yang nyaman bagi anak sangatlah penting untuk dijaga oleh orang tua. Salah satu tugas orang tua ialah menyediakan rasa aman, nyaman dan menyenangkan. Kenyamanan dan rasa aman anak dapat diciptakan dengan memberikan kasih sayang, perhatian dan membangun kedekatan seperti rangkulan, pelukan dan belaian orang tua. ${ }^{65}$ Lingkungan yang tenang, aman dan nyaman akan memberikan semangat untuk belajar. ${ }^{66}$ Kenyamanan yang dirasakan akan meningkatkan kemampuan untuk menerima informasi dan pengajaran yang lebih maksimal. Ilmu dan petunjuk akan lebih mudah diserap dan dilaksanakan sehari-hari. Mawarsih mengutip pendapat Slameto mengatakan bahwa ikatan yang penuh empati dan kasih sayang dari orang tua, dibarengi tuntunan dan petunjuk akan mendukung belajar anak. ${ }^{67}$

${ }^{62}$ Helmawati, Pendidikan Keluarga: Teoritis dan Praktis (Bandung: Remaja Rosdakarya, 2014), 50.

63 Ibid, 50.

${ }^{64}$ Adrian, Irfan, "Peran Orang Tua sebagai Pendidik Anak Dalam Keluarga" EDUGAMA: Jurnal Kependidikan dan Sosial Keagamaan Vol.3 No.2 (Desember 2017): 153.

${ }^{65}$ Euis Kurniati, Dina Kusumanita, Fitri Andriani, "Analisis Peran Orang Tua dalam Mendampingi Anak di Masa Pandemi Covid-19" Jurnal Obsesi: Jurnal Pendidikan Anak Usia Dini vol.5 no.1 (Mei 2021): 247.

${ }^{66}$ Siska Eko Mawarsih, "Pengaruh Perhatian Orang Tua dan Motivasi Belajar Terhadap Prestasi Siswa" Jurnal UNS Vol.1 No.3 (Juni 2013): 5.

67 Ibid. 


\section{Melatih Anak-anak}

Orang tua melatih anak dengan melakukan beberapa cara, 1) Mengajak. Anak sebaiknya diajak untuk hadir dalam ibadah keluarga dan melihat. 2) Melatih. Orang tua memberikan kepercayaan untuk terlibat dalam berbagai aktivitas, ${ }^{68}$ contohnya memimpin doa atau bernyanyi. 3) Menyemangati. Dorongan dari orang tua sangat diperlukan untuk menumbuhkan minat dan semangat bagi anak, termasuk jika anak gugup atau gagal.69 4) Menghargai. Anak-anak perlu dihargai dengan memberikan pujian terhadap sesuatu yang dia telah usahakan. Ini dapat meningkatkan rasa percaya diri untuk lebih giat melakukannya kemudian. ${ }^{70} \mathrm{Hal}$-hal ini diharapakan dapat menumbuhkan ketertarikan yang kuat dan kemandirian anak terhadap ibadah keluarga.

Ibadah keluarga dapat menjadi tempat untuk melatih anak-anak. Dengan melibatkan anak dalam ibadah keluarga akan memberikan kesan yang mendalam tentang firman yang dipelajari dan mencintai ibadah. Menurut Al-Faruq cara agar anak tekun melakukan ibadah adalah dengan memberikan contoh bagaimana ayah dan ibu melangsungkan ibadah dan tata cara beribadah yang dilihat langsung oleh anak. ${ }^{71}$ Dengan melatih anak mengetahui dan terbiasa melakukannya.

\section{Orang Tua Sebagai Konselor}

Dalam pertumbuhan seorang anak memerlukan pendampingan. Sebagai konselor sangatlah perlu bagi orang tua untuk berbincang-bincang dengan anak terkait tantangan dan persoalan anak atau tentang rahasia yang dimiliki. ${ }^{72}$ Pendekatan melalui bimbingan dan konseling dapat mengembangkan potensi dan mengentaskan masalah yang menjadi hambatan. ${ }^{73}$ Orang tua menjadi konselor yang sangat efektif bagi anak mereka karena ada keterikatan batin dan memiliki lebih banyak waktu dibandingkan sekolah dan lingkungan lainnya, ${ }^{74}$ terutama pada tahun-tahun permulaan pertumbuhan mereka. Sebagai konselor orang tua berperan untuk tidak menghakimi atau mempersalahkan anak, namun

68 Ulfa Nili Zakiyah, "Peran Orang Tua dalam Meningkatkan Kemandirian Belajar" (Skripsi, Institut Agama Islam Negeri Ponorogo, 2020), 30.

${ }^{69}$ Ahmad Susanto, Pendidikan Anak Usia Dini (Konsep dan Teori), (Jakarta: Bumi Aksara, 2017), 59.

70 Kanisius, Membuat Prioritas, Melatih Anak Mandiri (Yogyakarta: Pustaka Familia, 2006), 21-22.

${ }^{71}$ Asadulloh Al-Faruq, Mendidik Balita Mengenal Agama, (Solo: Kiswah Media, 2010), 27.

72 Neng Lani Ligina, “Peran Orang Tua Dalam Pencegahan Kekerasan Seksual ...” Jurnal Keperawatan Vol.9 No.2 (Juli 2018): 112.

${ }^{73}$ Galang Surya Gumilang, "Peran Orang Tua Sebagai Non-Direct Service Dalam Bimbingan dan Konseling” Jurnal Fokus Konseling Vol.3 No.1 (Januari 2017): 4.

74 Ibid. 7-8. 
membimbing dan mengarahkanpada apa yang sepatutnya. ${ }^{75} \mathrm{Hal}$ ini sangat bermanfaat dalam perkembangan pemahaman peribadi terhadap berbagai hal termasuk bidang kerohanian.

\section{Implikasi}

Peran orang tua untuk meningkatkan kualitas ibadah keluarga dengan memberikan contoh yang benar sejak dini agar anak dapat memperhatikan dan meniru, selanjutnya anak diajarkan untuk terlibat misalnya membawakan doa, disini anak butuh didampingi dengan memberikan dorongan dan bila kesulitan orang tua dapat menyebutkan doa beberapa kalimat. Apabila anak belum bisa sebaiknya tidak dimarahi tetapi memberikan motivasi dan mengatasi hambatan yang menjadikannya gagal.

Mengajarkan firman Tuhan bisa dilakukan dengan menceritakan cerita Alkitab, dengan bermain melalui alam, binatang dan berbagai aspek kehidupan yang dikaitkan dengan kebesaran Tuhan. Praktik ibadah keluarga sebaiknya menjadi kebiasaan yang tetap dalam setiap rumah tangga Kristen, misalnya dengan menentukan waktu yang tetap pada pagi dan petang.

\section{Kesimpulan}

Tempat pertama bagi anak-anak menerima pendidikan moral dan nilai-nilai rohani serta pembinaan iman ialah keluarga. Orang tua, sebagai pendidik pertama, bertanggung jawab untuk mengasuh secara terus menerus berulang-ulang dengan tiada jemu berdasarkan ajaran Alkitab melalui ibadah keluarga.

Orang tua memiliki peran penting dalam meningkatkan ibadah keluarga melalui keteladanan yang diberikan, memberikan rasa nyaman dan situasi yang menyenangkan bagi anak, berperan sebagai pendidik, melatih dan melibatkan anak dalam ibadah keluarga serta hadir sebagai konselor yang memberi motivasi. Dalam memberi edukasi, orang tua mengedepankan kasih sayang dan keharmonisan keluarga. Perilaku dan keteladanan orang tua memiliki peran dalam kerohanian, perilaku dan kebiasaan anak. Keberadaan orang tua di dalam keluarga haruslah menjadi sosok idola yang menggambarkan sosok Ilahi, yang pantas untuk diteladani.

Ibadah keluarga sangat penting untuk dilakukan setiap hari dalam keluarga. Anakanak perlu terbiasa melihat dan meniru praktik ibadah, ini dapat dipraktikkan di setiap waktu dan di setiap kesempatan yaitu pengenalan tentang Tuhan. Pada dasarnya hal-hal

\footnotetext{
${ }^{75}$ Lusyana Pratiwi, "Peran Orang Tua Dalam Mencegah Kenakalan Remaja ...” Diklus: Jurnal Pendidikan Luar Sekolah Vol. 1 No.1 (Maret 2017): 80.
} 
apa yang dilakukan di awal usia dini sangat mempengaruhi kehidupan anak pada masa kemudian.

\section{Referensi}

Adrian, Irfan. "Peran Orang Tua sebagai Pendidik Anak Dalam Keluarga" EDUGAMA: Jurnal Kependidikan dan Sosial Keagamaan Vol.3 No.2 (Desember 2017): 147-167.

Alexander, W.L. The Pulpit Commentary, vol. III. Grand Rapids MI: Wm. B. Eerdmans Publishing Company, 1980.

Al-Faruq, Asadulloh. Mendidik Balita Mengenal Agama. Solo: Kiswah Media, 2010.

Antone, Hope S. Pendidikan Kristiani Kontekstual. Jakarta: BPK Gunung Mulia, 2010.

Cairns, I. J. Tafsiran Alkitab Kitab Ulangan,_Jilid I. Jakarta: Gunung Mulia, 1997.

Clark, Adam. A Commentary and Critical Notes. New York: The Methodist Book Concern, 1984.

Darmawan, I Putu Ayub. "Pembelajaran Memorisasi dalam Ulangan 6:6-9," EPIGRAPHE: Jurnal Teologi dan Pelayanan Kristiani 3, no.1 (Mei 2019): 21-27.

Deane, W.J. dan S.T. Taylor Taswell, The Pulpit Commentary, ed. H.D.M. Spence dan Joseph Exell, Grand Rapids, MI: Eerdmans, 1950.

Departemen Pendidikan dan Kebudayaan, Kamus Besar Bahasa Indonesia, $2^{\text {nd }}$ ed. Jakarta: Balai Pustaka, 1987.

Departemen Pendidikan Nasional, Kamus Besar Bahasa Indonesia, $2^{\text {nd }}$ ed. Jakarta: Balai Pustaka, 2005.

Djamarah, Syaiful Bahri. Pola Asuh Orang Tua dan Komunikasi dalam Keluarga. Jakarta: Rineka Cipta, 2014

Exell, Joseph S. The Pulpit Commentary. New York: Funk and Wagnalls, 1950

EGW Writings Application Indoneisan Version 6.0.5. Ellen G. White Estate, Inc., 2020.

EGW Writings for Android. Ellen G. White Estate, 2013.

Gayel, Aby. Stimson Hutagalung dan Rolyana Ferinia, “Tantangan Mendidik Anak-Anak Pendeta di Gereja Masehi Advent Hari Ketujuh (GMAHK) DKI Jakarta Melalui Penerapan Disiplin dan Keteladanan," EDULEAD: Journal of Christian Education and Leadership, Vol. 2, Edisi.1 (Juni 2021): 102-119. 
Goldsteini, Clifford R. Kebenaran Zaman Ini dalam Kitab Ulangan. Bandung: Yayasan Penerbit Advent Indonesia, 2021.

Gumilang, Galang Surya. "Peran Orang Tua Sebagai Non-Direct Service Dalam Bimbingan dan Konseling” Jurnal Fokus Konseling Vol.3 No.1 (Januari 2017): 1-11.

Hartian, Santi. "Pengaruh Pembinaan Rohani Di Keluarga Terhadap Karakter Pemuda Berdasarkan Kolose 2: 6-10 Di GBAP Surakarta," Journal Fidei, Vol.2 No.1 (Juni 2019): 20-39.

Heath, Stanley Warren. Keluarga Kristen: Antisipasi Pengaruh Pendidikan Global dalam Keluarga. Bandung: Biji Sesawi, 2016.

Helmawati, Pendidikan Keluarga: Teoritis dan Praktis. Bandung: Remaja Rosdakarya, 2014.

Hitami, H. Munzir. Mengonsep Kembali Pendidikan Islam. Yogyakarta: LkiS, 2004.

Hutagalung, Stimson. \& Rolyana Ferinia, "Menjelajahi Spiritualitas Milenial: Apakah Membaca Alkitab, Berdoa, dan Menghormati Ibadah di Gereja Menurun?," Jurnal Teruna Bhakti, Volume 2, No 2, (Pebruari 2020): 97-111

Indriyanto, Exnasius. Pengaruh Pola Asuh Orang Tua Terhadap Iman Anak. Yogyakarta: Sanata Dharma, 2008.

Iskandar, Salman. 99 Tokoh Muslim Indonesia. Bandung: Mizan, 2009.

Jalaluddin, Psikologi Agama. Jakarta: Rajawali Pers, 2012.

Kanisius, Membuat Prioritas, Melatih Anak Mandiri. Yogyakarta: Pustaka Familia, 2006.

Kartono, Kartini. Patologi Sosial 2 Kenakalan Remaja. Jakarta: Rajawali, 1986.

Kementerian Keuangan Republik Indonesia, "Memahami Metode Penelitian Kualitatif" https://www.djkn.kemenkeu.go.id (diakses 14 Juni 2021, 09.28 WITA)

Kurniati, Euis. Dina Kusumanita, Fitri Andriani, “Analisis Peran Orang Tua dalam Mendampingi Anak di Masa Pandemi Covid-19" Jurnal Obsesi: Jurnal Pendidikan Anak Usia Dini vol.5 no.1 (Mei 2021): 241-256.

Lembaga Alkitab Indonesia, Alkitab Terjemahan Baru. Jakarta: LAI, 2014.

Ligina, Neng Lani. “Peran Orang Tua Dalam Pencegahan Kekerasan Seksual ...” Jurnal Keperawatan Vol.9 No.2 (Juli 2018): 109-118. 
Mawarsih, Siska Eko. "Pengaruh Perhatian Orang Tua dan Motivasi Belajar Terhadap Prestasi Siswa" Jurnal UNS Vol.1 No.3 (Juni 2013): 1-13.

Meyers, Rick. e-Sword Electronic edge. (www.e-Sword.net, 2020).Morrison, Geoffrey Stewart. Teaching the Classical Hebrew Stem System. British Columbia: Vancouver School of Theology, 1995.

Narramore, Clyde M. Menolong Anak Anda Bertumbuh dalam Iman. Bandung: Yayasan Kalam Hidup, 1961.

Nugrahani, Farida. Metode Penelitian Kualitatif Dalam Penelitian Pendidikan Bahasa. Surakarta: 2014.

Nurwardani, Paristiyanti. dkk, Buku Ajar Mata Kuliah Wajib Umum Pendidikan Agama Kristen. Jakarta: Direktorat Jenderal Pembelajaran dan Kemahasiswaan Kementerian Riset Teknologi dan Pendidikan Tinggi, 2016.

Online Bible Study Suite https://biblehub.com/

Owens, John Joseph. Analytical Key to the Old Testament, vol. I. Grand Rapids, Michigan: Baker Book House Company, 1990.

Pratiwi, Lusyana. “Peran Orang Tua Dalam Mencegah Kenakalan Remaja ...” Diklus: Jurnal Pendidikan Luar Sekolah Vol. 1 No.1 (Maret 2017): 75-83.

Rowlley, HH. Ibadat Israel Kuno. Jakarta: BPK Gunung Mulia, 2012.

Salim, Peter. Kamus Bahasa Indonesia Kontemporer, $3^{\text {rd }}$ ed. Jakarta: Balai Pustaka, 1991.

Sarumpaet, R.I. Pedoman Rumah Tangga. Bandung: Indonesia Publishing House, 1991.

Sirait, Jerry Rudolf . Ied Veda Sitepu dan Albert M Hutapea, Sekarang, Bangkit dan Berdirilah, Jangan Goyah. Jakarta: PrimaLogi Press, 2004.

Sjamsuri, Leonardo A. Keluarga Bahagia Ditengah Perubahan Zaman. Jakarta: Nafiri Gabriel, 2016.

Smit, Brigitte. "Observations in Qualitative Inquiry: When What You See Is Not What You See," Sagepub: International Journal of Qualitative Methods Volume 17: 1-3): 1-4.

Soelaeman, M.I. Pendidikan Dalam Keluarga. Bandung: Alfabeta, 1994.

Stamps, Donald. Alkitab Penuntun Hidup Berkelimpahan. Malang: Gandum Mas, 2003.

Susanto, Ahmad. Pendidikan Anak Usia Dini (Konsep dan Teori). Jakarta: Bumi Aksara, 2017.

Togatorop, Kavolder. "Pengaruh Peningkatan Ibadah Dalam Keluarga Terhadap Karakter Remaja Kristen Di Yayasan Perguruan Anugerah Sinagoge SMPTK Medan," PROVIDENSI: Jurnal Pendidikan dan Teologi, Volume 3, Nomor 1 (Juni 2020): 5266. 
“Teach" (Deutronomy 6:7), The Seventh-Day Adventist Bible Commentary, ed. Francis D. Nichol, Washington, D C.: Review and Herald, 1978.

Utley, Bob. Kumpulan Komentari Panduan Belajar. Vol 3. Texas: Bible Lesson International, 2005.

Waharman, "Peran Orang Tua Dalam Pertumbuhan Spiritualitas Anak: Sebuah Studi Eksegesis Efesus 6:1-4," Manna Rafflesia, 4/2 (April 2018): 116-129.

Wahyuningtyas, Nuraini. "Kasjian Tentang Pengasuhan Babysitter Terhadap Kemampuan Berbicara Anak Usia 2-3 Tahun” Skripsi Fakultas Ilmu Pendidikan, Universitas Negri Semarang, 2016.

Wijanarko, Jarot. Mendidik Anak. Banten: PT. Happy Holy Kids, 2012.

Yusuf, Syamsu. Psikologi Perkembangan Anak dan Remaja. Bandung: Remaja Rosda Karya, 2004.

Zakiyah, Ulfa Nili. "Peran Orang Tua dalam Meningkatkan Kemandirian Belajar" Skripsi, Institut Agama Islam Negeri Ponorogo, 2020. 